\title{
THE FACTORS INFLUENCING THE EMERGENCE OF UNETHICAL BUSINESS BEHAVIOUR
}

\author{
Piroska Dobos*, Katalin Takács-György**
}

\begin{abstract}
Background. Non-ethical business behaviour and the causes of the hidden economy are examined extensively through multiple research methods. The aim of the research is to expand the classical economics' statements to the fullest extent of the phenomenon, according to which tax avoidance depends on the number of checks, degree of punishment, income level of the individuals, and the extent of the tax rates - which are within the fields of sociology and behavioural science.
\end{abstract}

Research aims. The purpose of the study is to summarise the results of earlier research related to the possible behavioural patterns and forms of behaviours behind the hidden economy.

Methodology. The main direction of the study is to evaluate the change in the classical economics model - maximising the expected usefulness - along with the field of behavioural economics. The present study examines the possibility of application of the Rosenberg self-esteem scale - which is widespread and utilised for the measurement of self-esteem in the international pieces of research - concerning whether the extent of the self-esteem of the individual may affect the engagement with the hidden economy. After the evaluation of the questionnaire surveys, naturally we expect the suggested research assumptions to be confirmed.

Key findings. Also, both the cultural environment and the demographic factors may have an impact on tax morals, and national pride, also the higher levels of trust among citizens in the government, tax authorities and other legal institutions may also have a beneficial effect. In addition, friendly and respectful treatment of taxpayers, handling them as partners can also improve the willingness to pay taxes, the direct political participation of citizens, and involvement in political decisions, and democracy can have a significant impact on tax morals as well.

Keywords: hidden economy, attitude, government, tax morals, economic psychology.

\footnotetext{
* Óbuda University - Budapest, Hungary. E-mail: d.piri@globalprofit.hu

** Óbuda University - Budapest, Hungary. E-mail: takacsnegyorgy.katalin@kgk.uni-obuda.ku
} 


\section{INTRODUCTION}

Originating from their tax sovereignty, individual economies have their own taxation systems, but because of the ever-increasing international trade relations, they keep trying to harmonise domestic legislation with international law. Due to the high degree of globalisation and the expansion among the member states of the European Union, competition has crossed borders, and competitiveness has become a determining factor in international relations. The institutional system of the European Union has a special place in international law. Because of its specific nature, it is not comparable to international organisations or to the institutional system of the states, as both intergovernmental and supranational elements occur. Both the emergence of the unified European market and the abolition of border controls, also the development of Community trade have contributed greatly to the spread of tax avoidance, tax evasion, and tax denial. This results in a reduction in budget revenue, a violation of the principle of fair tax burdens and the distortion of Community competition conditions. For this reason, it is very important for the member states to develop methods for cooperation, mutual exchange of information, appropriate expansion and coordination of administrative and legal instruments, presence in tax inspections in other member states, and continuous exchange of experience. Countries where taxpaying is easier and the trust towards the taxpayer is greater can expect more revenue. With high tax rates and high administrative burdens, however trust also decreases. States have reduced tax administration burdens over the past few years by introducing self-taxation, but the use of electronic declarations and methods of group taxation has also spread (Herich et al., 2011). In Hungary, in recent years, the corporation tax has declined, except for the last two years, but has changed continuously with the rate of the personal income tax. The rate of the simplified corporate tax introduced in 2003 has been more than doubled since 2003 , from 15 to 25 and then to $37 \%$. Perhaps this is one of the main problems of the Hungarian tax system today, namely that there is no foresight. According to Gáspár et al. (2004), the horizontal and vertical equity is strikingly not present in the Hungarian taxation system because of the exceptions and exemptions and the different taxation forms of certain various incomes, also the taxation system 
cannot be considered to be effective, enforceable or transparent either. According to Szerb and Ulbert (1998), the most frequently criticised feature of the Hungarian tax system is the correlation between the high tax burdens, the over-taxation of the middle class, the complex and slowly not at all transparent system, the tax system, and the ratio of the black / grey economy to be about 30\%, also the untransparent expenditure side, the frequent wasting of the resources, and corruption.

In the life of the National Tax and Customs Office (NAV), a turning point was the year 2016. This year the process started to make NAV a non-tax office, but a provider of services acting in a way that supports taxpayers' affairs. The aim of the transformation is to create a tax office that cooperates with customers to effectively meet the social and government expectations, by transforming the culture of administration and by creating the availability of services, taxpayers are encouraged to make fair tax payments. For this reason, a supportive procedure was formed that helps to correct defaults and mistakes instead of immediate punishment. The main goal is to operate a credible, client-centric National Taxation and Customs Administration, which is accepted by the society and at the same time improves voluntary observance and tax morale (NAV Évkönyv, 2016). The choice of topic - the factors influencing the tax morals and the examination of these - therefore, because of the reform of the tax authority, is very timely and necessary.

\section{BACKGROUND}

\section{Factors affecting willingness to pay taxes}

Conclusions to be derived from the classical models. Two territories of the modern economy contributed to the setting out of the models regarding the hidden economy.

- The first territory is the social welfare maximisation approach or the concept of optimum taxation. This is used to determine the tax rate that maximises social welfare, which can be described by a social welfare function that takes into account the impact of taxes on labour supply, wealth generation, and income distribution.

- The second territory is the microeconomics of crime. Its practitioners start from the base of models in which the offender 
rationally assesses the expected benefits and costs of crime, and chooses the alternative that maximises the (net) expected benefits (Szántó \& Tóth, 2001).

The model of Allingham and Sandmo (1972) is a pioneer among models examining taxpayers' behaviour, and further develops the model of Becker $(1968,1976)$. According to the classical approach, the individual decision determining the rational behaviour of taxpayers in profit maximisation (i.e. the choice of taxpayers between the observation of law and tax evasion) depends on the following factors (Semjén, 2017):

1. the income level of the taxpayer,

2. the tax rates,

3. the probability of being controlled/being caught,

4. the extent of penalty.

Under the classic model of tax evasion, individuals decide on their tax behaviour by assessing the expected impacts of the above variables rationally (as a homo oeconomicus taking into consideration the calculations based on the expected utility of the outputs). In this, the offender rationally assesses the expected benefits and costs of crime, and chooses the alternative that maximises the expected (net) benefits. Benefit maximising actors, in finding a solution for some forms of emergence in the hidden economy (for example, in the case of tax evasion) are looking for an optimal solution, counting on the costs and benefits of participation in or staying away from the hidden economy. According to the model, the rise in probability of getting caught always leads to the increase in declared income. Accordingly, by increasing the probability of control, the proportion of concealed income can probably be reduced.

Corchòn's model (1992) is for coexistence of economic actors; the taxing state tries to comply with these punishments, and presents the role of a criminal of a citizen trying to escape from his obligations. Likewise, the choice between the curve and the straight path is shown by Isaac Ehrilch's model (1973). The taxpayer can choose between two paths or activities, the legal path to the attainment of goods (correct conduct) and the illegal path of acquisition of property (crime strategy). The entrance costs are not taken into account when entering the two activities nor the costs of movements between the activities. Individuals will most likely choose a combination of the two activities, as it is presumed that there are few who live with crime. It is more likely that a legal activity is behind the crime in the background, as a cover story. 
The choice of the variables in the classical model is very logical, and the assumed direction of the effect of these variables on tax behaviour is generally based on reasonable theoretical considerations. The results of the empirical tests sometimes do not point to the expected direction and often contradict each other. In the research of this topic, the "classical model" of the individual taxation decision on risk is transformed into increasingly new and more complex approaches, enabling the emergence of conflicts between individual and societal interests and tax heterogeneity, the different motivations of the different actors and the consideration of psychological aspects determining the tax behaviour (Semjén, 2017).

To understand and control the functioning of economies, we need to see clearly the thought patterns that animate people's ideas and feelings, i.e. the spiritual factors. We cannot truly understand important economic events unless we are faced with the fact that these factors are - taking into consideration their nature - mainly psychological ones (Akerlof \& Shiller, 2011).

Based on the economic theory of criminal behaviour, the rate of taxes paid or suffered by citizens depends on a simple cost-benefit calculation. As many studies have shown, these models identify important factors but cannot explain the behaviour of taxpayers (Kirchgässner, 2010). In order to properly pay their taxes, individuals need motivation that cover more than simple economic calculations, other factors also play an important role.

After the turn of the millennium, several pieces of research have examined whether values, societal norms, and attitudes differ from country to country and that these differences have a measurable impact on economic behaviour. One area where such studies are particularly important is tax compliance (Alm \& Torgler, 2005). Tax compliance seems to depend on a number of factors, ranging from deterrence to individual economies, level of fines and revision ratios (combined with available risk aversion estimates) in most countries. The deterrence models, however, indicate too much leniency and only a small amount of tax evasion.

The existence and direction of the relationship between the tax rates and the observation of laws is a controversial issue in the special literature, if not to the same extent as the relationship between income and the lawful conduct. In the assessment of the impact of tax rates, the standard model itself is ambivalent and empirical literature does 
not give a clear picture, although empirical evidence suggests that the negative impact of high tax rates on legitimate tax attorneys is significantly more than the opposite (Semjén, 2017). Large tax reforms and tax reductions do not necessarily reduce the size of the hidden economy, but rather stabilise the given level. Many studies have shown a positive relationship between the size of the hidden economy and the increase in tax burdens, but in the case of tax reductions, the relationship remained insignificant (Schneider, 1997). We also find this in Frey and Feld (2002) that the basic model of tax evasion (Allingham \& Sandmo, 1972), based on the maximisation of the expected usefulness that is not particularly successful in subjective econometric analysis, shows too little tax evasion and the econometric estimates of the parameters likelihood and the level of fines are not as effective as they hoped. Therefore, it is advisable to extend these models with different variations.

It should be kept natural that businesses want first and foremost through the reduction of tax and contribution burdens, and less of the controls and penalties are tightened by hoping to reduce the hidden / black economy (Belyó, 2008). The classic way of reducing the hidden economy is to increase the size of punishment. This solution seems fairly obvious and is widely used. At the same time, there are models of game theory that the penalty does not affect the offense (Semjén et al., 2001). The probable punishment in the case of tax evasion depends on the likelihood of falling and not on the amount of punishable punishment. Excessive punishment can, however, reduce marginal deterrence. If people are being severely punished for less tax evasion, they are more likely to make more tax evasion because the marginal punishment for larger fraud is smaller. Government and public administration can reduce the tax rates and regulatory intensity, thus reducing the strength of the motive to engage in a hidden economy. In other words, efforts should be made to approach the socially optimal rate of taxation and regulation. Cummings et al. (2004) found that an increase in the likelihood of controls and the level of fines would increase compliance with the tax liability, but the impact of tax rates is not clear.

In 2006 Schneider and Torgler carried out a unique study of citizens' tax morals in three multicultural European countries, Switzerland, Belgium, and Spain, based on World Values Survey data. The results show that the deterrence factors do not have a significant impact on the tax attitudes, and the coefficient of the penalty rate is in most 
cases negatively significant and the tax rate has no significant effect on tax morale.

The impact of demographic factors, the cultural environment, national pride, and religious values on willingness to pay taxes. There is considerable evidence that coercion efforts may increase compliance with tax rules, but extreme punishments may even have counterproductive effects - resulting in lower tax payments and the loss of general trust in state institutions. Furthermore, it has also been observed that compliance with the tax liability is different in individual countries and cultures. Significant literature is available, indicating that compliance with the rules is influenced by social norms (Elster, 1989). To develop tax-reduction policies, it is essential to understand the behavioural attitudes behind the decision-making of tax compliance. It is desirable to develop tax policies that encourage tax compliance within the existing tax system. If the individual attitudes of compliance are dependent on social and cultural norms, then the improvement of these norms may be a desirable political option. Compliance with the tax liability is a complex behavioural problem and its examination requires the use of different methods and data sources, as each asset has its advantages and shortcomings. Cummings et al. (2004) report on laboratory tests in South Africa and Botswana using the same tax reporting report in all experimental environments. The willingness to pay tax has been studied using both empirical data and data obtained from laboratory experiments. Survey data allows many socio-economic, demographic, and attitudinal variables to be included in the use of multivariate analyses. Both empirical and laboratory data show that cultural norms have an impact on tax willingness to pay.

Kirchler's (1997) study also examines the attitude of taxpayers. Reliance on norms, egoistic and altruistic value orientation, tax mindset and tax morale, and demographic characteristics were assessed by questionnaires. The results show that value orientation, age and dependence on norms are also related to general tax attitudes. The taxation mentality and tax morale, as Schmölders (1960) have determined, depends on the age of respondents. This result was confirmed on several occasions in the relevant literature (Kirchler, 1996; Strümpel, 1969). With increasing age, taxpayers can adapt to the tax system and learn to accept it. It can be assumed that these results are also influenced by the fact that older people rely more heavily on the 
pension system and other state support networks than young people who feel that their leave is limited by tax payments and they do not perceive that the use of paid taxes or redistribution would be fair or inappropriate for government feedback on the use of tax burdens. In a later Kirchler (1999) study, we find that personality characteristics, ideological, and religious values influence tax evasion.

Lewis (1982) and Groenland and Van Veldhoven (1983) report that personality characteristics (such as dependence on norms), ideological and religious values, and moral orientations influence tax morale. According to Kirchler (1999), taxes limit the freedom of individuals to make autonomous decisions about their income. For this reason, they are likely to respond to opposition to their freedom of restraint or perceived limitations. This inductive resistance is due to the perceived restriction of freedom, probably due to taxpayers' attitudes, tax evasion and tax behaviour changes. The age of respondents in the survey, the demographic characteristics of the participants, such as the gender of the respondents, also significantly influenced the tax attitudes.

According to Kirchgässner (2010), taxation morals depend on religious traditions and the relationship between political and religious authorities. In addition, individual factors such as age, gender, marital status, and employment status, as well as more general assessment indicators, such as trust in the government and the legal system, have a significant positive impact on tax morale. The same applies to the degree of decentralisation, while the efficiency of the public sector has a negative effect. In addition, cultural factors and especially religious behaviour play an important role: religious people have a higher tax burden. For example, research in Canada has produced results that Catholics have lower tax morals than Protestants, but this is still an open question because the difference is statistically insignificant.

The results of the study by Schneider and Torgler on the Wald-test of 2006 show that cultural and regional differences affect tax dignity. Based on the Swiss survey, it has been found that culture plays a significant role in determining the individual tax morality. Examining national pride, they also came to the conclusion that it also has an impact on the tax morals. With respect to the other control variables, a trend was observed in the case of women that the tax morale was significantly higher than for men. In addition, people of 50-64 years of age tend to have a greater willingness to pay than in the case of other 
age groups. In addition, married people experienced higher tax morale than single persons and pensioners. In the case of Belgian surveys, the role of culture on the willingness to pay taxes, as well as national pride and democratic attitudes have been studied. The results do not show statistically significant differences between the different cultural groups as in Switzerland. Similarly to the Swiss results, national pride and democratic attitudes in Belgium have a significant positive impact on tax morals. It is worth noting that national pride and democratic attitudes have more effect on the tax morals of the French-speaking population than among the Flemish population. As far as demographic variables are concerned, the particularly high taxation morale in the 50-64 age group suggests the positive impact of age. Moreover, women clearly have higher tax morale than men, and married people are also at higher tax morals than single people, like the Swiss example. According to the multivariable analysis in Spain, the Wald test shows that culture plays a significant role in defining individual tax mores, and national pride and democratic attitudes have a significant positive impact on it. The results on control variables suggest that women are more accountable for tax payments than men and widows show the highest tax morale for private individuals. The study's findings show that cultural and regional differences affect both taxation morale in Switzerland and Spain. In addition, in all three countries, results have emerged that national pride and democratic attitudes have a positive impact on the willingness to pay tax, which can prove that the higher legitimacy of political institutions leads to higher tax compliance.

Belyó (2004) conducted studies on tax morale. Among the respondents, there were also companies which were also in the conduct of economic actors to explore the factor that could help to suppress the hidden economy. According to $13 \%$ of the survey, the current economic standards need to change at least a generation. While 9\% say that this is not enough, there will always be companies that find and use the loopholes, and $4 \%$ of them do not see a company having any interest in changing the current situation.

The impact of the relationship between the state, state institutions, and taxpayers on the willingness to pay taxes. Tax compliance, in addition to the above, depends on a number of factors. Alm et al. (1995) were followed by experiments in Spain and the United States. The two countries are very different in both culture and history. They found that subjects in the United States consistently 
achieved higher compliance than participants in the same experiments in Spain and attributed these differences to compliance with higher social standards in the United States. In line with the experiments, the results show that there is a significantly higher tax morality in the United States than in Spain - considering three different years - based on WVS data.

Schmölders (1960) analysed tax evasion among self-employed people in Europe and concluded that the tax burden on self-employed taxpayers is lower than that of taxpayers who already work for other persons or organisations. Strümpel (1969) also analysed the tax evolution between European taxpayers. He conducted an international comparative survey in Europe, which compared the tax system of different European countries and the level of tax evasion between taxpayers in some countries. He found that tax morals in Germany were relatively low, while in England they were relatively high. In his view, the main difference between the German and the English tax systems at this time was that the German government used compelling fiscal control techniques while the English system treated taxpayers with more respect and less control. The English system has helped to increase the tax burden by this method.

According to Frey and Feld (2002), the tax burden of taxpayers increases when tax officials pay respect to them. Conversely, when tax officials rely solely on the deterrence of taxpayers, they tend to react to trying to actively avoid paying taxes. It has also been shown that the authoritarian approach more strongly suppresses tax evasion and that citizens have fewer political participation rights. By contrast, a respectable approach and high political participation rights for citizens greatly increase tax morals.

Taxation limits the freedom of individuals to make autonomous decisions about their income (Kirchler, 1999). It can also be assumed that employers that have been running their business for a while now feel less comfortable with their tax payer's freedom than entrepreneurs who have only just started their operations. Research has also shown that the perceived limitation of freedom is interrelated with the positive attitude towards tax evasion. A number of studies also support the fact that people in financial difficulties are willing to pay less than others, and the importance of feeling personality, ideological and religious values, moral orientation and sense of truth, within the economic system, tax willingness to pay. 
Frey and Torgler (2006) used research results from EVS data, based on a sample of 30 countries - examining at least 1,000 individuals in each country. In most transition countries, citizens do not pay taxes at the start of the transition process. Direct political participation of taxpayers is also of great importance for the willingness to pay tax, direct political participation leads to lower tax evasion and leads to higher internal motivation for tax payments. The quality of political institutions has a strong impact on tax morals, political stability, non-violence, government efficiency, quality of regulation; rule-of-law, and corruption are also strongly influenced by tax morals.

Cummings at al. (2004), coercion efforts may increase compliance with tax rules, but extreme punishments may even have counterproductive effects - resulting in lower tax payments and the loss of general trust in state institutions. From a comparative analysis of Botswana and South Africa - the geographically neighbours are very different in terms of their social history. In South Africa, tax evasion is treated as a serious offense, while in Botswana, the tax authority's attitude is much more service-oriented. The British colonial rules have made visible successes in Botswana since it was the fastest growing economy in the world for the last 35 years.

Alm et al. (1995) and somewhat later (1999) examined the tax attitudes, tax ties, or internal motivation for taxation in the Russian economy. The results suggest that a higher level of confidence in the state has a positive effect on tax evasion. Tax evasion is common in transition countries. High tax evasion jeopardizes the government's ability to provide basic services. The tax attorney's attitude to citizens depends on many factors. The assessment of the social norms and the performance of public institutions is clearly a crucial factor for the citizens. In addition, tax attitudes depend on the level of specific factors such as personal, demographic, and attitudinal characteristics. The main determinant of tax morals is trust in government and legal institutions. Tax mores positively affect people's trust in the government and justice system. National pride can also be an important factor, which determines tax morality. In the 1990s, the Russian tax enforcement strategy was based on strong coercion methods, mainly on increasing the mandate of growing law enforcement agencies. The results of the research show that, in parallel, tax morals have declined sharply in Russia.

The role of trust as an emotional attitude in the functioning of the modern market economy is so significant that many areas and 
phenomena of the economy cannot be analysed without having a clear picture of this, but the phenomenon of evasion, which is indispensable, is irreconcilable with this subject, emerges - undermines trust (Hámori, 1998). Kirchler et al. (2010) the strength of the tax authority and the proper size of trust in the tax authority should be understood as the rounded and voluntary tax payments. In a hostile environment taxpayers and tax authorities work against each other while in a synergistic climate they work together. In the hostile environment there is likely to be great social distance, little respect for the authorities, so voluntary tax payments are negligible and citizens take advantage of tax evasion. By contrast, in the case of a "public service and customer" approach, the authorities aim to support the taxpayers. For example, in Switzerland, friendly and respectful treatment by the authorities is an important resource for taxpayers, which has long been recognised to enhance compliance with tax rules. The power of the tax authorities and trust in the tax authorities together affect the level of tax compliance (Kirchler et al., 2007). If trust in the authorities is low and the power of the authorities is weak, it is likely that citizens will strive to maximise their individual achievements by circumventing taxes - the structure that demonstrates this correlation in their research on the slippery slope - "slippery-sloping" structure.

Schneider et al. (2012) analysed the shadow economy by the MIMIC method for the period 1999-2010 in 39 OECD countries (including Hungary). The impact of a higher shadow economy on official GDP data leads to an expected negative value and reduces government revenue. Tax policy and state regulatory factors have an impact on the black economy, which if grown, then the black economy will also increase.

Schneider and Torgler (2006) also state that evidence suggests that implementation efforts cannot fully explain the high degree of tax compliance. They are also involved in their research - using the World Values Survey (WVS) and European Values Survey (EVS) data - as the primary dependent variable for culture, institutions, political attitudes, religion, probability, and fines.

In Schneider's (2000) research of 18 OECD countries, we find that one of the reasons for the hidden economy is the high tax burden, but there are several reasons for the effects of regulations, the complexity and transparency of the tax system, and the attitude of taxpayers towards the state. Schneider also points out that when the government changes the tax structure, for example, introduces a reduction in direct 
tax burdens, it expects that the hidden economy will also be reduced. He noticed, however, that even in the case of major tax reforms, when significant tax cuts were made, the hidden economy continued to grow.

Schneider et al. (2015) also state that still the main driving forces of the shadow economy are indirect taxes, followed by self-employment and unemployment. Hence, these are the most efficient policy options to reduce the shadow economy.

\section{The effect of self-esteem on the willingness to pay taxes}

The relationship between money and self-esteem. The concept of self and its component of evaluation, self-assessment, are one of the most researched phenomena of personality and social psychology, the health-psychological aspects of which are also significant. It is generally assumed that people are strongly motivated to maintain and protect their high self-esteem (Komlósi, 2007). Self-evaluation is a relatively stable, feature-like characteristic that can be related, for example, to age or gender, but is also associated with many health indicators. In other longitudinal studies, the low level of self-assessment by Rosenberg Self-Esteem Scale predicted some aspects of adult health and behaviour in adolescence, such as worse financial outcomes, weaker physical and mental health, and higher risk of crime commitment (Trzesniewski, 2006).

Numerous studies also study the relationship between money and self-esteem, two factors that people generally desire. The relationship between money and self-esteem can be: increase, substitution, and competition. The augmentation effect shows that excellent payment opportunities increase the level of self-esteem. The substitution effect means that money and self-esteem can partially compensate for each other. The symbolic meaning of money, the individual differences, and the extent of the need for money affect how money and self-esteem can substitute each other. The competition effect emphasises people's choice between money and self-esteem. Money and self-esteem compete against each other when decision makers have to choose between them. These theories can help bridge the gap between psychology and economics and provide an integrative perspective for understanding human decision-making (Zhang, 2009).

There are also studies in the literature on the exploration of the relation between money and self-esteem, low self-esteem and greater risk 
of crime (Trzesniewski, 2006; Zhang, 2009; Hanley-Wilhelm, 1992; Norvilitis et al., 2006) the aim is to examine the direct relationship between self-esteem and tax evasion - through the Rosenberg self-esteem scale.

Rosenberg Self-Esteem Scale, RSES. The questionnaire was developed by Rosenberg (Rosenberg, 1965; 1989) to measure "global" self-esteem. Nowadays, this is the most commonly used appraisal questionnaire. It contains ten (5 positive and 5 negative) statements about the value of self and self-acceptance. Using a four-point Likert scale ( 1 - strongly disagree, 2 - disagree, 3 agree, 4 - strongly agree) the respondent can indicate how much he or she agrees with each statement. The reliability and validity of the scale is demonstrated by a number of test samples (e.g. adolescents, elderly people, and psychiatric patient groups) and research results obtained in different cultures. There are several translation versions in Hungary. The language used in the later translations is simpler than that of the previous versions, but it can be stated that the scale was always reliable and valid regardless of translation differences. The factor structure of the measuring instrument has also been studied in a number of domestic and international studies, and the results mostly support the validity of the one-dimensional factor structure, but also indicate that positively and negatively-defined items are separate. The two-dimensional structure stems from the methodological distortion that the positive and negative content-generated items result in systematic variance, which is more due to the distorting effect of the response style rather than the construct (Komlósi, 2017). In our questionnaire, which is currently being tested in Hungarian, we use the translation version of Sallay et al. (2014).

\section{METHOD}

The purpose of this paper is to develop a questionnaire for the assessment of the following research questions and to define the examination criteria:

- the taxpayer's income level, tax rates, the probability of control/ getting caught, and the amount of punishment on the tax willingness to pay;

- the impact of demographic factors (gender, age, marital status, qualifications, and number of children) on the tax morals;

- the impact of national pride on tax willingness to pay; 
- the friendly and respectful treatment of taxpayers, their impact on tax willingness to treat them as partners;

- direct political participation of citizens, involvement in political decisions, the impact of democracy on the tax morals.

The method used to analyse the studied literature is content analysis.

The questionnaire was compiled on the basis of the results of the above-mentioned international literature, complemented by self-constructed questions. Questions in the questionnaire are closed questions, I offer pre-defined responses, and the participants should choose the appropriate ones. Test queries on paper basis - under supervision were done individually. After testing the questionnaire and making the necessary changes, I am planning to use an online questionnaire to reach a larger sample.

\section{RESULTS}

\section{Measurement methods of the shadow economy}

Generally speaking, the shadow economy can be measured in two ways: micro-level surveys, questionnaires, interviews, observations or indirect approaches such as demand for currency and hidden variables, using macroeconomic indicators. The direct estimation of the hidden economy is mostly based on the composition of Multiple Indicators Multiple Causes (MIMIC) and the demand for currency demand. MIMIC means that there are more indicators, more reasons, that is to say, the shadow economy, taking into account more aspects. The MIMIC procedure assumes that the hidden economy is an observable phenomenon (a hidden variable) that can be used to estimate the measurable causes of illegal employment such as tax burden and regulatory intensity, indicators of illegal activity, demand for currency, and official working hours. The disadvantage of this method is that it is only a relative estimate of the development and size of the hidden economy.

In addition, there are a large number of World Values Survey (WVS) and European Values Survey (EVS) data sets that enable the conduct of empirical studies within the subject. It contains factors on a personal level that may affect citizens' attitudes towards paying taxes. The WVS is a set of data on the world-wide survey of socio-cultural and political attitudes that contains the value of comparative data and across belief 
systems across the world. The EVS data set is a similar survey focusing solely on EU countries. Both surveys have been widely used by political scientists and economists. Using the World Values Survey (WVS) and the European Values Survey (EVS) data series, we can analyse the impact of social norms and government institutions by controlling the personal factors in a multiple regression analysis where tax morals are subordinated variables. Although each of the methods has weaknesses and strengths that will certainly prevail in the estimates of the hidden economy, it is obvious that the shadow economy cannot be measured accurately. Macro estimates from the MIMIC model and demand for currency are considered to be the upper limit of estimates, while micro level estimates are considered as the lower limit of estimates.

In our further research, we selected the method of questionnaire surveys for the first time to measure the factors and attitudes that motivate entry into the black economy, with the aim of supporting the relationships revealed on the basis of the previously published international literature, but we will not neglect to compare the results of the measurements with the other listed methods either. Testing the questionnaire and probe questionnaires are planned for the competent tax related decision-makers of small and medium-sized enterprises in Hungary of various sizes and activities.

\section{Factors influencing the attitude towards taxation}

According to classical models, control probability has a positive effect on taxpayers' compliance, and the degree of punishment has a considerable deterrent effect. Comparing our hypotheses with the investigators of the topic, however, it can be concluded that the positive effects of control probabilities are supported by empirical studies, while the degree of punishment is less clear. There are also significant contradictions regarding the impact of income and tax rates on tax morality (Table 1).

Since our analysis focuses on economic actors, individual decision-makers, and the behavioural features, decision alternatives, economic reactions of these economic actors, and so on, the motivations behind economic-investment decisions are far from being rational. Classical economics' models identify important factors, but they cannot explain the behaviour of taxpayers, so it is expedient to extend investigations in sociology and behavioural fields as well. 
Table 1. Deductible conclusions from classical models

\begin{tabular}{|c|c|c|c|}
\hline & Positive effect & Negative effect & Contradictions \\
\hline $\begin{array}{l}\text { Income level } \\
\text { of the tax- } \\
\text { payer }\end{array}$ & - & $\begin{array}{l}\text { Schneider - } \\
\text { Torgler (2006) }\end{array}$ & $\begin{array}{l}\text { Semjén (2017), Kirchler } \\
\text { et al. (2010), Semjén - } \\
\text { Szántó - Tóth (2001) }\end{array}$ \\
\hline Tax rates & $\begin{array}{l}\text { Belyó (2004), Belyó } \\
\text { (2008) }\end{array}$ & Semjén (2017) & $\begin{array}{l}\text { Sisak (2007), Schneider } \\
\text { (1997), Cummings et al. } \\
\text { (2004), Schneider - Tor- } \\
\text { gler (2006), Raczkowski } \\
\text { (2014), Raczkowski (2015) }\end{array}$ \\
\hline $\begin{array}{l}\text { Probability of } \\
\text { controlling/ } \\
\text { getting caught }\end{array}$ & $\begin{array}{l}\text { Semjén (2017), Belyó } \\
\text { (2004), Semjén - Szántó } \\
\text { - Tóth (2001), Cum- } \\
\text { mings et al. (2004) }\end{array}$ & - & - \\
\hline $\begin{array}{l}\text { The extent of } \\
\text { the penalty }\end{array}$ & $\begin{array}{l}\text { Belyó (2004), Cum- } \\
\text { mings et al. (2004) }\end{array}$ & $\begin{array}{l}\text { Semjén - Szántó } \\
\text { - Tóth (2001) }\end{array}$ & $\begin{array}{l}\text { Frey - Feld (2002), Sem- } \\
\text { jén (2017), Kirchler et al. } \\
\text { (2012) Semjén - Szántó } \\
\text { - Tóth (2001), Alm et al. } \\
\text { (1995) }\end{array}$ \\
\hline $\begin{array}{l}\text { The shortcom- } \\
\text { ings of classic } \\
\text { models }\end{array}$ & $\begin{array}{l}\text { Hámori (1998), Semjén } \\
\text { (2017), Kirchgässner } \\
\text { (2010), Alm - Torgler } \\
(2005)\end{array}$ & & \\
\hline
\end{tabular}

Source: own elaboration.

Based on the studied literature (Table 2), it has been confirmed that both the cultural environment and the demographic factors (gender, age, and marital status) have an impact on tax morals. Based on the experiments carried out in Botswana and South Africa, it is clear that cultural norms have an impact on tax willingness to pay. In the surveys conducted in the three multicultural European countries, Switzerland, Belgium, and Spain, we found that although there was less impact in Belgium in Switzerland and Spain it can be shown that the cultural environment has a significant influence on the tax willingness to pay. For all three countries, the results show that, apart from cultural factors, national pride has a positive impact on tax morals, although fewer literature data are available, so this requires further research. Among the cultural factors, religious attitudes play an important role in terms of taxation propensity. Within demographic factors, for all three countries, the results show that women's willingness to pay taxes is higher. In the case of the Swiss and Belgian surveys, there was higher tax morale than married 
people, and the Spanish results showed that the widow's willingness to pay tax was higher. In addition, there are countless studies on demographic factors that have a significant impact on tax willingness to pay, i.e. age, demographic characteristics of participants, such as gender and marital status, which are also related to general tax attitudes, i.e. the taxation mentality and the tax morale depends on the demographic characteristics of the respondents.

Table 2. The impact of demographic factors, the cultural environment, national pride and religious values on the willingness to pay taxes

\begin{tabular}{|l|l|}
\hline \multicolumn{1}{|c|}{ Main thoughts } & \multicolumn{1}{|c|}{ Author(s) } \\
\hline $\begin{array}{l}\text { The values, norms of the societies and attitudes } \\
\text { differ from country to country - they have a mea- } \\
\text { surable effects on the economic behavior }\end{array}$ & Alm - Torgler (2005) \\
\hline $\begin{array}{l}\text { The demographic factors have an effect on tax } \\
\text { moral }\end{array}$ & $\begin{array}{l}\text { Schneider - Torgler (2006), Kirchler } \\
\text { (1997; 1999), Kirchgässner (2010) }\end{array}$ \\
\hline The taxpayer's age has an impact on the tax moral & $\begin{array}{l}\text { Kirchler (1996; 1997; 1999), } \\
\text { Schmölders (1960), Strümpel (1969), } \\
\text { Kirchgässner (2010) }\end{array}$ \\
\hline $\begin{array}{l}\text { The taxpayer's gender has an impact on the tax } \\
\text { moral }\end{array}$ & $\begin{array}{l}\text { Kirchler (1999), Kirchgässner } \\
\text { (2010), Schneider - Torgler (2006) }\end{array}$ \\
\hline $\begin{array}{l}\text { The taxpayer's marital status has an impact on } \\
\text { the tax moral }\end{array}$ & $\begin{array}{l}\text { Kirchgässner (2010), Schneider - } \\
\text { Torgler (2006) }\end{array}$ \\
\hline $\begin{array}{l}\text { The cultural environment has a significant impact } \\
\text { on the tax willingness to pay }\end{array}$ & $\begin{array}{l}\text { Schneider - Torgler (2006), Kirch- } \\
\text { gässner (2010), Cummings et al. } \\
\text { (2004) }\end{array}$ \\
\hline Religious values & Kirchler (1999), Kirchgässner (2010) \\
\hline The national pride has an impact on the tax moral & Schneider - Torgler (2006) \\
\hline
\end{tabular}

Source: own elaboration.

Despite the fact that tax policy is the most obvious means of enforcing and regulating tax payments, the policy of deterrence - that is, the greater the imposition of penalties and fines, or the imposition or coercion can be offset by taxpayers. Coercion and extreme high taxes and penalties may result in lower tax payments and, in general, loss of trust in state institutions. Of course, it is worth noting that the US tax morale surpasses each country because tax morals prove more effective when taxpayers are better treated and there is 
involuntary intervention by public authorities. In addition, the large tax tide measured in the United States and Switzerland can mean that more demanding direct democratic elements may increase the tax morale. In a comparative study of the English and German tax systems, we could see that tax morals were lower in Germany than in England. The difference can be due to the specificities of the two tax systems, while in Germany there are compelling fiscal control techniques, while in England, respectful treatment with taxpayers is present.

In the experimental studies on deterrence and mood, we also find that the tax burden of taxpayers increases when officials are treated with respect, whereas deterrence leads to tax evasion. The quality of political institutions, the stability of the tax system, non-violence have a strong impact on tax morals, and direct political participation leads to higher internal motivation for paying taxes. Higher levels of confidence in the state favourably affect tax evasion, while tax enforcement, based on highly compulsive methods, reduces tax incentives. If there is a lack of trust and respect for the authorities, it leads to tax evasion. In contrast to this, we can introduce Switzerland's example, where friendly and respectful treatment by authorities is an important resource to enhance compliance with tax legislation. It can be concluded, therefore, that tax policy and state regulatory factors have a significant impact on the shadow economy (Table 3).

Table 3. The impact of the relationship between state, state institutions, and taxpayers on the willingness to pay taxes

\begin{tabular}{|l|l|}
\hline \multicolumn{1}{|c|}{ Main thoughts } & \multicolumn{1}{|c|}{ Author(s) } \\
\hline $\begin{array}{l}\text { A higher level of confidence in the state and public institu- } \\
\text { tions has a positive effect on the tax moral }\end{array}$ & $\begin{array}{l}\text { Alm et al. (2005), Frey - } \\
\text { Torgler (2006), Cummings } \\
\text { et al. (2004) }\end{array}$ \\
\hline Dealing with taxpayers with more respect and less control & $\begin{array}{l}\text { Strümpel (1969), Frey - } \\
\text { Feld (2002), Kirchler et } \\
\text { al. (2010) }\end{array}$ \\
\hline $\begin{array}{l}\text { Direct political participation of taxpayers has a positive } \\
\text { impact on the willingness to pay taxes }\end{array}$ & Frey - Torgler (2006) \\
\hline $\begin{array}{l}\text { The impact of regulations, the complexity and transparency } \\
\text { of the tax system have a positive impact on the willingness } \\
\text { to pay taxes }\end{array}$ & $\begin{array}{l}\text { Schneider et al. (2000), } \\
\text { Schneider et al. (2012) }\end{array}$ \\
\hline
\end{tabular}

Source: own elaboration. 


\section{CONCLUSIONS}

The "white" and the "hidden" economies exist side by side, but we know little about this "common being" and it is even harder to track how they operate and what behavioural rules govern in this relationship (Belyó, 2012). Due to the parallel existence, several studies have attempted to integrate the hidden economy into macroeconomic models in order to better handle the hidden economic model parts. Fleming argues strongly that not all hidden economic activities should be universally prevented (Fleming et al., 2000). Furthermore, empirical research by Schneider (1998) has shown that $66 \%$ of the income generated in the hidden economy is practically spent in the white sector, thus having a positive impact on economic growth and indirect tax revenue. Furthermore, Belyó (1999) points out that in developing countries where unemployment is high, unofficial activities are necessities for the population, and they may never disappear at $100 \%$. It is obvious that there is an optimum degree of the hidden economy in every economy, where it is not worth to increase further and the fiscal expenditures for fiscal control should not be further reduced (Szántó \& Tóth 2001). Although the existence and growth of the hidden economy can have both beneficial and disadvantageous consequences, it must not be forgotten that it operates illegally and its tolerance undermines tax discipline. Moreover, its rise can lead to a complete collapse of the economy, legality, and social order - and the declining state revenues due to tax evasion are a major problem in financing public goods and services. Combating tax evasion and the hidden economy and reducing their scale is an important policy goal for each country.

Extending the topic to examine the relationship between self-esteem and tax evasion will hopefully further contribute to understanding the phenomenon in order to create a more acceptable tax culture. The reform of the tax administration in 2016, in which the tax office participates as a service provider in a tax-oriented manner, is perhaps exactly the right starting point for developing this tax culture. In co-operation with clients, it complies with social and government expectations instead of strictness, punishment and coercion, encouraging taxpayers to pay taxes fairly through the transformation of the culture of administration and the availability of services. Hopefully, with the help of these methods - with the aid of attitudes and behaviour - the human decisions 
and the attitude towards paying taxes can be changed, without any coercion or economic incentives.

\section{REFERENCES}

Akerlof, G.A. \& Shiller, R.J. (2011). Animal Spirits - How Human Psychology Drives the Economy, and Why It Matters for Global Capitalism. Princeton: Princeton University Press.

Allingham, M.G. \& Sandmo, A. (1972). Income tax evasion: A theoretical analysis. Journal of Public Economics, 1, 323-338.

Alm, J. \& Torgler, B. (2005). Culture differences and tax morale in the United States and in Europe. Journal of Economics Psychology, 2, 224-246.

Alm, J., Martinez-Vazquez, J. \& Torgler, B. (2005). Russian attitudes toward paying taxes - before, during, and after transition. International Journal of Social Economics, 12, 832-857.

Alm, J., Sanchez, I. \& de Juan, A. (1995). Economic and noneconomic factors in tax compliance. Kyklos, 48(1), 3-18.

Becker, G.S. (1968). Crime and Punishment: An Economic Approach, University of Chicago and National Bureau of Economic Research. Chicaco: University of Chicago Press.

Belyó, P. (1999). Kisérletek a rejtett gazdaság nagyságának meghatározására. Budapest: Ecostat.

Belyó, P. (2004). A vállalkozások és a rejtett gazdaság. Statisztikai Szemle, 1, 61-63.

Belyó, P. (2008). A rejtett gazdaság nagysága és jellemzői. Statisztikai Szemle, 2, 113-137.

Belyó, P. (2012). A rejtett gazdaság előretörése az új gazdaságpolitikai gyakorlat következtében, XXI. Század - Tudományos Közlemények, 27, 25-46.

Corchòn, L.C. (1992). Tax evasion and the underground economy. European Journal of Political Economy, 8, 445-454.

Cummings, R.G., Martinez-Vazquez, J., McKee, M. \& Torgler, B. (2004). Effects of culture on tax compline: A cross check of experimental and survey evidence. CREMA, Working Paper No. 13, 29-31.

Ehrlich, I. (1973). Participation in illegitimate activities. Journal of Political Economy, 81, 521-575.

Elster, J. (1989). Social norms and economic theory. Journal of Economic Perspectives, 3(4), 99-117.

Fleming, M., Roman, J. \& Farrel, G. (2000). The shadow economy. Journal of International Affairs, 53(2), 64-89. 
Frey, B.S. \& Feld, L.P. (2002). Deterrence and morale in taxation: An empirical analysis. CESifo Working Paper No. 760, 7-9.

Frey, B.S. \& Torgler, B. (2006). Tax morale and conditional cooperation. Journal of Comparative Economics, 1, 136-159.

Gáspár, P., Halász, A. \& Lepp-Gazdag, A. (2004). Az államháztartás múködési problémái. Munkafüzet 3. ICEG Európai Központ, 18-20.

Groenland, E.A.G. \& Van Veldhoven, G.M. (1983). Tax evasion behaviour: A psychological framework. Journal of Economic Psychology, 3, 129-144.

Hámori, B. (1998). Érzelemgazdaságtan. Budapest: Kossuth Kiadó.

Hanley, A. \& Wilhelm, M.S. (1992). Compulsive buying: An exploration into self-esteem and money attitudes. Journal of Economic Psychology, 13(1), 5-18.

Herich, Gy. (ed.) (2011). Nemzetközi adózás. Adózás az Európai Unióban. Pécs: Penta Unió.

Kirchgässner, G. (2010). Tax Morale, Tax Evasion, and the Shadow Economy. St. Gallen: Department of Economics, University of St. Gallen.

Kirchler, E. (1996). Reactance to Taxation: Employers' Attitudes towards Taxes [paper presented at the 12th IAREP Annual Colloquium. Paris, France].

Kirchler, E. (1997). The burden of new taxes: Acceptance of taxes as a function of affectedness and egoistic versus altruistic orientation. Journal of Socio-Economics, 4, 421-437.

Kirchler, E. (1999). Reactance to taxation: Employers' attitudes toward taxes. Journal of Socio-Economics, 2, 131-138.

Kirchler, E., Hoelzl, E. \& Wahl, I. (2007). Enforced versus voluntary tax compliance: The "slippery slope" framework. Journal of Economic Psychology, 2, 210-225.

Kirchler, E., Muehlbacher, S. \& Kastlunger, B. (2010). Why pay taxes? A review of tax compliance decisions. In: J. Alm, J. Martinez-Vazquez \& B. Torgler (eds.). Developing Alternative Frameworks for Explaining Tax Compliance (pp. 15-31). London: Routledge.

Komlósi, V.A. (2007). Napjaink önértékelés-kutatásainak áttekintése. Önértékelés és/vagy önelfogadás? Személyiséglélektantól az egészségpszichológiáig. Budapest: Trefort Kiadó.

Komlósi, V.A., Rózsa, S., Nagy, S.Z., Köteles, F., Sági, A. \& Jónás, E. (2017). A vonásönbecsülés/-önértékelés kérdőives mérésének lehetőségei. Alkalmazott Pszichológia, 17(2), 73-108.

Lewis, A. (1982). The Psychology of Taxation. Oxford: Martin Robertson.

NAV évkönyv (2016). Tények, információk a Nemzeti Adó- és Vámhivatal szervezetéról és annak 2016. évi tevékenységérôl. Budapest: NAV.

Norvilitis, J.M., Merwin, M.M., Osberg, T.M., Roehling, P.V., Young, P. \& Kamas, M.M. (2006). Personality factors, money attitudes, financial knowledge, and 
credit-card debt in college students. Journal of Applied Social Psychology, 36(6), 1395-1413.

Raczkowski, K. (2014). Intellectual capital management in tax administration and country's economic growth determined by competitive taxation. In: K. Raczkowski, L. Sulkowski (eds.). Tax Management and Tax Evasio (p. 62). Frankfurt: Peter Lang Academic Research.

Raczkowski, K. (2015). Measuring the tax gap in the European economy. Journal of Economics and Management, 21(3), 70.

Rosenberg, M. (1965). Society and Adolescent Self-image. Princeton: Princeton University Press.

Rosenberg, M. (1989). Society and the Adolescent Self-image. Middeltown: Wesleyan University Press.

Sallay, V., Martos, T., Földvári, M., Szabó, T. \& Ittzés, A. (2014). A Rosenberg Önértékelés Skála (RSES-H): alternatív fordítás, strukturális invariancia és validitás. Mentálhigiéné és Pszichoszomatika, 15(3), 259-275.

Schmölders, G. (1960). Das Irrationale in der öffentlichen Finanzwssenschaft. Hamburg: Rowolt.

Schneider, F. \& Buehn, A. (2012). Shadow Economies in Highly Developed OECD Countries: What Are the Driving Forces?, 1-31. http://www.econstor.eu/ bitstream/10419/67170/1/727543865.pdf (accessed: $\left.2^{\text {nd }} J u l y ~ 2018\right)$.

Schneider, F. \& Torgler, B. (2006). What shapes attitudes toward paying taxes? Evidence from multicultural European countries, Working Paper No. 0608. Linz: Department of Economics, Johannes Kepler University of Linz.

Schneider, F. (1997). The shadow economies of western Europe. Journal of the Institute of Economic Affairs, 17(3), 42-48.

Schneider, F. (1998). Stellt das starke Anwachsen der Schwarzarbeit eine wirtschaftspolitische Herausforderung dar? Einige Gedanken aus volkswirtschaftlicher Sicht. Linz: Institut für Angewandte Wirtschaftsforschung.

Schneider, F. (2000). The Increase of the Size of the Shadow Economy of 18 OECD Countries: Some Preliminary Explanations. http://www.econstor.eu/bitstream/10419/73324/1/wp0008.pdf (accessed: $2^{\text {nd }}$ July 2018).

Schneider, F., Raczkowski, K. \& Mróz, M. (2015). Shadow economy and tax evasion in the EU. Journal of Money Laundering Control, 18(1), 46.

Semjén, A. (2017). Az adózói magatartás különféle magyarázatai. Közgazdasági Szemle, LXIV évf., 140-184.

Semjén, A., Szántó, Z. \& Tóth, I.J. (2001). Adócsalás és Adóigazgatás; Mikröokonómiai modellek és empirikus elemzések a rejtett gazdaságról. Elemzések a rejtett gazdaság magyarországi szerepéról, 3. tanulmány. Budapest: MAT-KTI TÁRKI. 
Strümpel, B. (1969). The contribution of survey research to public finance. In: T. Alan, T. Peacock (eds.). Quantitative Analysis in Public Finance (pp. 14-32). New York: Praeger.

Szántó, Z. \& Tóth, I.J. (2001). A rejtett gazdaság és az ellene való fellépés tényezói. Közgazdasági Szemle, 3, 203-218.

Szerb, L. \& Ulbert, J. (1998). A magyar adórendszer reformjának alapelveihez. Bankszemle, 42 évf, 6-7, 9-21.

Trzesniewski, K.H., Donnellan, M.B., Moffitt, T.E., Robins, R.W., Poulton, R. \& Caspi, A. (2006). Low self-esteem during adolescence predicts poor health, criminal behaviour, and limited economic prospects during adulthood. Developmental Psychology, 42, 381-390.

Zhang, L. (2009). An exchange theory of money and self-esteem in decision making. Review of General Psychology, 13(1), 66-76. 


\title{
CZYNNIKI WPKYWAJĄCE NA POJAWIENIE SIĘ NIEETYCZNYCH ZACHOWAŃ W BIZNESIE
}

\begin{abstract}
Abstrakt
Tło badań. Nieetyczne zachowania biznesowe oraz przyczyny szarej strefy sa szeroko analizowane poprzez różnorodne metody badawcze. Celem dochodzenia jest rozszerzenie klasycznych oświadczeń ekonomicznych w najszerszym zakresie zjawiska, zgodnie z którym unikanie opodatkowania zależy od liczby kontroli, surowości kary, poziomu dochodów osób fizycznych i wysokości stawek podatkowych, które mieszczą się w zakresie socjologii i nauk behawioralnych. Ponadto, zarówno środowisko kulturowe, jak i czynniki demograficzne mogą mieć wpływ na sumienność płacenia podatków. Duma narodowa, wyższy poziom zaufania wśród obywateli w stosunku do rządu, organów podatkowych i innych instytucji prawnych moga również mieć korzystny wpływ. Przyjazne i pełne szacunku traktowanie podatników jako partnerów może również poprawić gotowość do płacenia podatków, a także bezpośredni udział polityczny obywateli i zaangażowanie w decyzje polityczne oraz demokratyczne państwo.
\end{abstract}

Cel badań. Celem badania jest podsumowanie specjalistycznej literatury na temat możliwych wzorców zachowań oraz zachowań będących przyczyną szarej strefy.

Metodologia. Głównym kierunkiem badania jest ocena zmiany w klasycznym modelu ekonomii - maksymalizacja oczekiwanej użyteczności - wraz z założeniami ekonomii behawioralnej. Niniejsze badanie analizuje możliwość zastosowania skali samooceny Rosenberga - szeroko rozpowszechnionej i wykorzystywanej do pomiaru poczucia własnej wartości w międzynarodowych badaniach - dotyczącej tego, czy poziom samooceny danej osoby może wpływać na skłonność do działania w szarej strefie. Po ocenie badań ankietowych spodziewamy się, że odpowiedź brzmi „tak”.

Kluczowe wnioski. Zarówno środowisko kulturowe, jak i czynniki demograficzne mogą mieć wpływ na moralność podatkową i dumę narodowa. Również wyższy poziom zaufania obywateli do rządu, organów podatkowych i innych instytucji prawnych może przynieść korzystne efekty w tym obszarze. Ponadto przyjazne i pełne szacunku traktowanie podatników oraz postrzeganie ich jak partnerów może wpłynąć na skłonność do płacenia przez nich podatków. Także bezpośredni udział w życiu politycznym obywateli i ich zaangażowanie w proces decyzyjny oraz demokratyczny ustrój może mieć znaczący wpływ na moralność podatkową.

Słowa kluczowe: ukryta gospodarka, postawa, rząd, moralność podatkowa, psychologia ekonomiczna. 